\title{
Plastic mulch effects on ground beetle communities (Coleoptera: Carabidae) in an organic blueberry field
}

\author{
Efecto del uso de cubiertas plásticas sobre \\ las comunidades de carábidos (Coleoptera: Carabidae) \\ en un huerto de arándanos bajo manejo orgánico \\ Alejandra Ganter ${ }^{1}$, René Montalba ${ }^{2,3}$, Ramón Rebolledo $^{3}$, Lorena Vieli ${ }^{4}$
}

\begin{abstract}
A study was conducted to determine the effect of synthetic mulch on the diversity and abundance of carabid beetles in an organic blueberry crop. The treatments consisted of plastic mulch, plastic mulch combined with pine needles, pine needles only and bare soil as control. Beetles were captured using pitfall traps. The number of individuals collected was greater in the treatment consisting of mesh and pine needles and in bare soil, whereas the mesh treatment alone presented the lowest values. Species richness showed no differences between treatments. Although there were density differences among the treatments, further studies are needed in order to establish the preference of these insects for any particular groundcover more clearly. Nevertheless, the results suggest that the incorporation of vegetal material as mulch in the holes left open in the mesh for the plant may improve the capacity of synthetic covers to harbor carabid beetles and hence improve the biological control of pests, particularly in organic crops.
\end{abstract}

Key words: biological control, generalist predator, carabid beetles, microhabitat, mulch.

\section{RESUMEN}

Se realizó un estudio cuyo objetivo fue determinar el efecto del uso de cubiertas sintéticas sobre la diversidad y abundancia de carábidos en un huerto de arándanos bajo manejo orgánico. Los tratamientos evaluados consistieron en malla plástica, malla plástica combinada con acícula de pino, acícula de pino y un testigo de suelo descubierto. Las capturas se efectuaron utilizando trampas de caída (pitfall traps). El número de individuos colectados fue mayor en el tratamiento compuesto por malla combinada con acícula y en el testigo, mientras que el tratamiento compuesto solo por malla fue el que presentó los menores valores. En lo que respecta a riqueza de especies, no se evidenciaron diferencias estadísticamente significativas. Fue posible determinar diferencias entre los tratamientos, no obstante la interpretación de los resultados es compleja y se considera que se requieren más estudios que permitan explicar la preferencia de estos insectos por alguna cobertura en particular. No obstante, los resultados sugieren que la incorporación de material vegetal a las cubiertas sintéticas podría mejorar su capacidad de albergar carábidos y por tanto de mejorar los procesos de regulación biológica de plagas, especialmente en sistemas bajo manejo orgánico.

Palabras clave: control biológico, depredador generalista, carabid beetles, microhábitat, cubiertas de suelo.

\section{Introduction}

The use of inert cover over plantation rows is a widely used practice in blueberry (Vaccinium corymbosum L.) cultivation both in humid and arid zones, mainly because it improves water retention in the former and reduces weed growth in the latter (Pedreros \& Ovalle, 2005; Shaxon $\&$ Barber, 2005). Although it has been reported that organic cover can increment production in blueberry plants, the use of this material is not a viable alternative in Chile, both because of high

1 Universidad de La Frontera, Facultad de Ciencias Agropecuarias y Forestales, Magíster en Ciencias Agropecuarias. Francisco Salazar 01145, Temuco, Chile.

2 Universidad de La Frontera, Facultad de Ciencias Agropecuarias y Forestales, Departamento de Ciencias Agronómicas y Recursos Naturales. Francisco Salazar 01145, Temuco, Chile.

3 Universidad de La Frontera, Instituto del Medio Ambiente y Sustentabilidad. Montevideo 0835, Temuco, Chile.

4 Bren School of Environmental Science and Management, University of California, Santa Barbara, CA 93106, USA.

* Corresponding author: rene.montalba@ufrontera.cl

Fecha de Recepción: 8 Junio, 2012.

Fecha de Aceptación: 27 Agosto, 2013. 
cost and difficulty in obtaining or manipulating it (Montalba et al., 2008). Thus synthetic covers have gained popularity in recent years, especially polypropylene mesh, which has proved to be more effective in weed control and more durable than other synthetic covers (Gough, 1994).

Depending upon their characteristics, covers may alter diverse soil properties, including structure, humidity, temperature, organic matter content and others (Cook et al., 2006; Ramakrishna et al., 2006; Chakraborty et al., 2008). Also, the optical properties of the materials utilized modify the radiation balance in the soil surface, producing changes in temperature both under the cover and on the surface. These factors may affect positively or negatively the crop and other organisms present in agro systems, such as some populations of arthropods important in agriculture, including both pests and their natural enemies (Miñarro \& Dapena, 2003; Mathews et al., 2004; Szendrei \& Weber, 2009). The manipulation of the habitat of predatory arthropods, in this case by installing a cover, may alter not only the abundance but also the diversity of species present in the system, which could impact the efficiency of biological control by these organisms (Cardinale et al., 2006).

The carabids (Coleoptera:Carabidae) are a group widely used to study the effect of diverse agricultural management systems on the populations of beneficial arthropods (Grandchamp et al., 2005; Purtauf et al., 2005), since most are generalist predators abundant in agricultural systems, abundant in natural systems and play an important role in control of the pests of numerous crops, including blueberry (O'Neal, 2005). They are also vagile and sensitive to the conditions of the environment and the habitat, thus the study of carabid communities provides a good bio-indicator of the ecological quality and health of agricultural systems (Rainio \& Niemelä, 2003).

To determine the impact of the establishment of plastic cover (polypropylene mesh) in a blueberry crop system, we measured the abundance and diversity of carabid species as an indicator of the ecological quality of the system. The plastic mulch was compared to organic cover (pine needles) and a control without cover, and with a plastic mulch with incorporation of plant material (pine needles) in the openings of the net above the plantation rows.

\section{Materials and methods}

\section{Experimental site}

The study was performed in a blueberry plantation located $11 \mathrm{~km}$ from the city of Villarrica ( $\left.39^{\circ} 16^{\prime} \mathrm{S}, 72^{\circ} 13^{\prime} \mathrm{W}\right)$ in the Región de La Araucanía, Chile (Figure 1). Four acres of Elliott blueberries 8 years after plantation were used; the plantation has a $3 \times 0.8 \mathrm{~m}$ scheme. The entire plantation is managed organically (certified); no biocides were used on the insect populations.

\section{Experimental design}

Since it was hypothesized that the covers would generate habitat differences in the ecological system, which require large areas to develop, treatments were established in large blocks or macro-plots. In the specialized literature this is known as an "on farm" design, in which an un-replicated agriculturalecological design is compared to one with normal management (Altieri, 1999; Nicholls et. al., 2001). Thus the experimental area was divided into four macro-plots of $2500 \mathrm{~m}^{2}$ each, which were randomly assigned to the three treatments and the bare soil control.

Treatments consisted in placing different covers over the plantation lines: $\mathrm{T} 1$ was a net constructed of black polypropylene, commonly called an anti-weed net, which was placed in two strips on both sides of the plant stems; the space in the center was covered with pine needle $\left(100 \mathrm{~m}^{3} / \mathrm{ha}\right) \mathrm{s}$. T2 was the same net but without pine needles; T3 was a cover consisting of a $10 \mathrm{~cm}$ layer of pine needles $\left(400 \mathrm{~m}^{3} / \mathrm{ha}\right)$; $\mathrm{T} 4$ was the control, in which the ground was left uncovered.

Before beginning the treatments the plantation lines were weeded manually. They were maintained free of weeds during the experimental period by periodic manual weeding according to the requirements of each treatment. Spontaneous vegetation was maintained between the rows, dominated mainly by the grass Cynodon dactylon L., which was cut periodically in the study plots when it reached $15 \mathrm{~cm}$ height.

\section{Sampling}

Carabids were captured using pitfall traps, which were $300 \mathrm{ml}$ plastic containers of $7 \mathrm{~cm}$ diameter, one third full of a solution of soapy water and $10 \%$ 


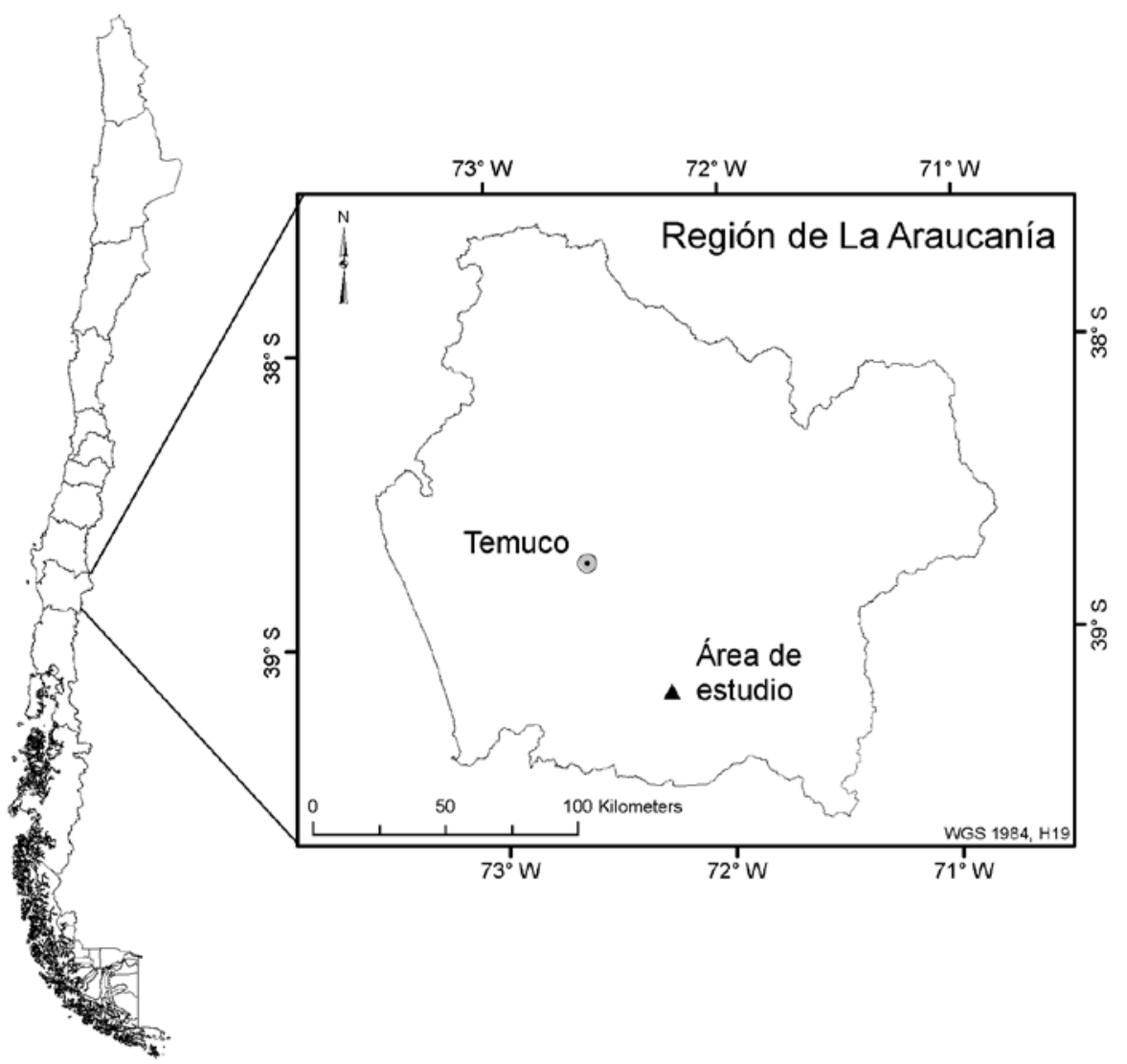

Figure 1. Location of the study site.

formalin. At $5 \mathrm{~cm}$ above the traps $12 \mathrm{~cm}$ diameter plastic disks were installed, supported by a steel wire framework. In each of the macro-plots we installed six groups of three traps each (18 traps) in the central part of the plantation rows. The mean of each group was used as one replicate. We sampled on five occasions between November, 2009 and March, 2010; each time the traps were left in place for ten days. When the traps were removed, the insects were immediately placed in plastic containers with $70 \%$ ethanol and refrigerated for later identification in the laboratory.

\section{Analysis of data}

The captured insects were used to estimate species abundance (number of individuals) and richness (number of species). After verifying that the assumptions of ANOVA were fulfilled, this was used $(\mathrm{p}<0.05)$ to compare among treatments along with the Tukey a posteriori test, in the software $\mathrm{R}$ v.2.15.0 (R Development Core Team, 2012).

\section{Results}

A total of 463 individuals were collected, which belong to 16 species of carabids. The six most abundant species included $96.3 \%$ of the total (Table 1). The most abundant species was Trirammatus aerea (Dejean) with 215 individuals, $46.4 \%$ of the total. It should be noted that the most abundant species under the study conditions (fruit cultivation) are not the same as those found for woodland systems in other studies in the same region (Fierro et al., 2011).

\section{Abundance and diversity of carabids in the treatments (plantation rows)}

The mean number of individuals captured per trap was significantly greater in $\mathrm{T} 1$ (synthetic cover plus pine needles) and T4 (no cover); the lowest mean was that of T2 (synthetic cover only) (Figure 2). Species richness was not significantly lower in $\mathrm{T} 2$ 
Table 1 . Species of carabids collected in the study and relative proportions.

\begin{tabular}{lcc}
\hline Species & Abundance (N Ind.) & Proportion (\%) \\
\hline Trirammatus aerea (Dejean, 1828) & 215 & 46.4 \\
Trirammatus striatula (Fabricius, 1775) & 74 & 16.0 \\
Calosoma vagans (Dejean, 1831) & 55 & 11.9 \\
Trirammatus chalceus (Dejean, 1828) & 50 & 10.8 \\
Trirammatus unistriatus (Dejean, 1828) & 26 & 5.6 \\
Parhypates chilensis (Dejean, 1826) & 26 & 5.6 \\
\hline Subtotal & 446 & 96.3 \\
\hline Trechisibus sp. & 4 & 0.9 \\
Bradycellus sp.1 & 3 & 0.6 \\
Bradycellus sp.2 & 2 & 0.4 \\
Metius sp.1 & 2 & 0.4 \\
Metius sp.2 & 1 & 0.2 \\
Creobius eydouxii (Guérin-Ménéville, 1838) & 1 & 0.2 \\
Bembidion sp. & 1 & 0.2 \\
Parhypates extenuatus (Tschitscherine, 1900) & 1 & 0.2 \\
Systolosoma breve (Solier, 1849) & 1 & 0.2 \\
Ceroglossus chilensis (Eschcholtz, 1829) & 1 & 0.2 \\
\hline Total & 463 & 100 \\
\hline
\end{tabular}

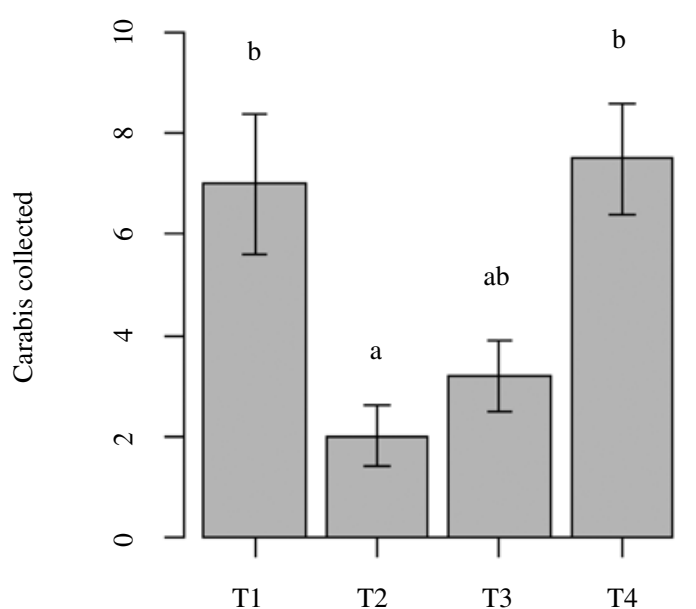

Figure 2. Abundance of carabid beetles (number of individuals collected) in treatments with different groundcover: $\mathbf{T 1}$, plastic mulch with pine needles; $\mathbf{T} 2$ plastic mulch; $\mathbf{T 3}$, Organic mulch (pine needles); T4, bare soil. The bars show the means of \pm standard error of means. Values followed by different letters are significantly different by the Tukey test $(\mathrm{p}<0.05)$.

and was greatest in $\mathrm{T} 4$, which is coherent with the other values obtained (Figure 3).

\section{Discussion}

It is interesting that the lowest number of captures was recorded for rows covered with polypropylene

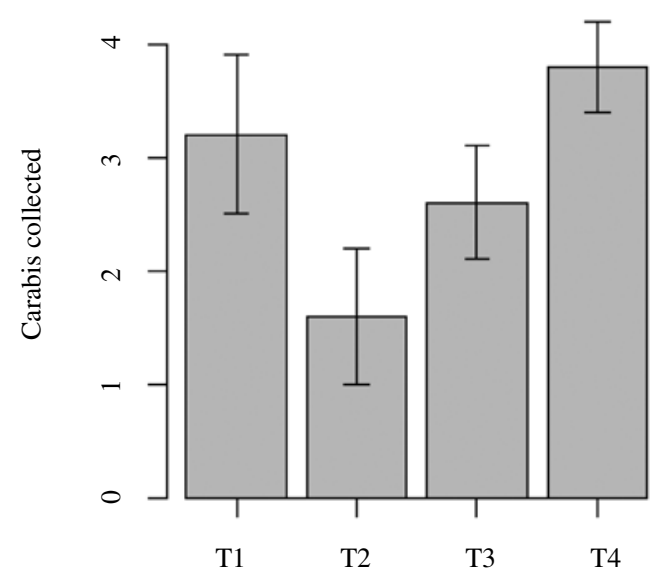

Figure 3. Species richness of carabid beetles (number of species collected) in trratments with diferent groundcover: T1, plastic mulch with pine needles; T2 plastic mulch; T3, Organic mulch (pine needles); T4, bare soil. Bars represent the means \pm standard errors of means. The treatments showed no significant differences $(\mathrm{p}>0.05 ; \mathrm{n}=6)$.

mesh (T2), compared to the other treatments and the control. This indicates the existence of a factor which reduces the colonization of carabids with only the mesh, while improving the habitat by adding pine needles increased colonization significantly. These results agree with those reported by Miñarro \& Dapena (2003), who found lower abundance of 
carabids in apple rows covered with plastic than rows without plastic and rows with organic cover (cereal stubble and pine bark). However, the fact that there were a larger number of captures in certain environments may not only due to a greater presence of carabids, but also to an increase in their movement activity, which in turn may be related to anthropic perturbation such as manual weeding (Holland \& Smith, 1999) and/or environmental factors such as temperature and food availability (Raworth y Choi, 2001). Among the anthropic perturbation factions, the high amount of weeds in the treatment without cover (T4) and the continual manual weeding required to maintain the rows open may have affected the mobility of the carabids and have influenced the increment of their capture. The number of captures recorded with synthetic cover (T2) may be due to this inert material providing less availability of alternative food (such as saprophytes) for generalist predators such as the carabids (Ceccanti et al., 2007). In agreement with this interpretation, Mathews et al., (2004) demonstrated that plastic cover significantly reduced the availability of alternative food for the complex of soil predators present in an apple orchard, while a cover of compost, high in organic matter, favored the presence of both alternative prey and predators. Similarly, working with spiders, Birkhofer et al. (2008) showed that the presence of organic matter triggered an increment in the availability of alternative prey (mainly dipteran larvae) and that this produced an increase in spider abundance and their control over aphids in wheat. The presence of alternative prey may favor early predator colonization, which is a key factor to achieve effective biological control during the season (Settle et al., 1996). This effect associated with organic cover may also be relevant in the control that some carabid species exert in pests of high economic significance in blueberry crops and which are difficult to control in systems under organic management (especially Curculionidae).

Other relevant factors not measured in this study may have influenced the variation in carabid abundance found with different covers; they may represent different microclimatic conditions generated by the different cover types. According to Mathews et al. (2004), complex structures composed of plant remains are capable of providing adequate safe sites from other predators, which also protect the carabids from direct exposure to sunlight, resulting in increase in prey capture compared to those recorded using more simple structures. In this case the synthetic cover (T2) is a simple structure, while the cover with pine needles is more complex, thus the microclimatic conditions generated in these structures may explain the differences observed.

We conclude that the use of synthetic cover in blueberry crops significantly reduces the abundance of carabids. As a way to mitigate this effect and increment the capacity to house carabids, applying organic material to cover a fraction of the row is an effective crop practice. The information obtained in terms of the decrease in carabids mediated by the use of synthetic cover and its improvement by a simple, low cost procedure such as the application of low doses of organic material is relevant if we consider that the establishment of a polypropylene net is the only practice which is spreading for the control of weeds in organic blueberry crops; in these systems the processes of biological pest control associated with carabid species are particularly important.

\section{Acknowledgements}

We thank the Dirección de Investigación of the Universidad de La Frontera for financing as part of Project DI 11-0078 and also Agrícola Vida Nueva.

\section{Literature Cited}

Altieri, M. A.

1994. Biodiversity and Pest Management in Agroecosystems. Haworth Press, New York, NY, USA.

Birkhofer, K., Bezemer, T., Bloem, J, Bonkowski, M, Christensen, S., Dubois, D., Ekelund,F., A. Fließbach, A., Gunst, L., Hedlund,K., Mäder, P., Mikola, J., Robin, C., Setälä, H., Tatin-Froux, F., W. Van der Putten, W. and Scheu, S.

2008. Long-term organic farming fosters below and aboveground biota: Implications for soil quality, biological control and productivity. Soil Biology and Biochemistry, 40: 2297-2308.

Cardinale, B., Srivastava, D., Duffy, J., Wright, J., Downing, A., Sankaran, M. y Jouseau, C.

2006. Effects of biodiversity on the functioning of trophic groups and ecosystems. Nature, 443 (7114): 989-992.

Ceccanti, B., Masciandaro, G. y Macci C.

2007. Pyrolysis-gas chromatography to evaluate the organic matter quality of a mulched soil. Soil and Tillage Research, 97 (1): 71-78. 
Chakraborty, D., Nagarajan, S., Aggarwal, P., Gupta, V., Tomar, R., Garg, R., Sahoo, R., Sarkar, A., Chopra, U., Sundara Sarma, K. y Kalra, N.

2008. Effect of mulching on soil and plant water status, and the growth and yield of wheat (Triticum aestivum L.) in a semi-arid environment. Agricultural Water Management, 95 (12): 1323-1334.

Cook, H., Valdés, G. y Lee, H.

2006. Mulch effects on rainfall interception, soil physical characteristics and temperature under Zea mays L. Soil and Tillage Research, 91 (1-2): 227-235.

Gough, R.

1994. The highbush blueberry and its management. Food Products Press. New York, USA. 272 p.

Fierro, A., Zúñiga, A., Aguilera, A., Rebolledo, R.

2011. Carábidos (Coleoptera: Carabidae) presentes en un relicto vegetacional del llano central de La Araucanía. Idesia 29 (3): 87-97.

Grandchamp, A.C., Bergamini, A., Stofer, S., Niemela, J., Duelli,

P. y Scheidegger, C.

2005. The influence of grassland management on ground beetles (Carabidae: Coleoptera) in Swiss mountane meadows. Agriculture, Ecosystems and Environment, 110 (3-4): 307-317.

Holland, J. y Smith, S.

1999. Sampling epigeal arthropods: an evaluation of fenced pitfall traps using mark- release- recapture and comparisons to unfenced pitfall traps in arable crops. Entomologia Experimentalis et Applicata, 91(2): 347-357.

Mathews, C., Bottrell, D. y Brown, M.

2004. Habitat manipulation of the apple orchard floor to increase ground-dwelling predators and predation of $C y d i a$ pomonella L. (Lepidoptera: Tortricidae). Biological Control, 30 (2): 265-273.

Miñarro, M. y Dapena, E.

2003. Effects of groundcover management on ground beetles (Coleoptera: Carabidae) in an apple orchard. Applied Soil Ecology 23 (2): 111-117.

Montalba, R., Merino, E., Vieli, L.

2008. Evaluation of the large-scale organic transition process of blueberry orchards in Chile from an agroecological perspective. In: Book of abstracts 16 IFOAM World Congress, Modena, Italia, p. 91.

Moreno, M. y Moreno, A.

2008. Effect of different biodegradable and polyethylene mulches on soil propeties and production in a tomato crop. Scientia Horticulturae, 116 (3): 256-263.
Nicholls,C., Michael Parrella, M., y Altieri, M.A.

2001. The effects of a vegetational corridor on the abundance and dispersal of insect biodiversity within a northern California organic vineyard. Landscape Ecology, 16 (2): 133-146.

O'Neal, M., Zontek, E., Szendrei, Landis D. y Isaacs, R.

2005. Ground predator abundance affects prey removal in highbush blueberry (Vaccinium corymbosum) fields and can be altered by aisle ground covers. BioControl, 50 (2): 205-222.

R Development Core Team.

2012. R: A Language and Environment for Statistical Computing. R Foundation for Statistical Computing, Vienna, Austria. http://www.r-project.org.

Pedreros, A. y Ovalle, C.

2005. En Céspedes, M. C. Agricultura orgánica. Principios y prácticas de producción. Instituto de Investigaciones Agropecuarias (INIA) Quilamapu. Chillán, Chile. 131 p.

Purtauf, T., Roschewitz, I., Dauber, J., Thies, C., Tscharntke,

T. y Wolters, V.

2005. Landscape context of organic and conventional farms: Influences on carabid beetle diversity. Agriculture, Ecosystems and Environment, 108 (2): 165-174.

Rainio, J. y Niemelä, J.

2003. Ground beetles (Coleoptera: Carabidae) as bioindicators. Biodiversity and Conservation 12 (3): 487-506.

Ramakrishna, A., Tam, H., Wani, S. y Long, T.

2006. Effect of mulch on soil temperature, moisture, weed infestation and yield of groundnut in northern Vietnam. Field Crop Research, 95 (2-3): 115-125.

Raworth, D. y Choi, M-Y.

2001. Determining numbers of active carabid beetles per unit area from de pitfall-trap data. Entomologia Experimentalis et Applicata 98 (1): 95-108.

Settle, W., Ariawan, H., Astuti, E., Cahyana, W., Hakim, A.,

Hindayana, D. y Lestari, A.

1996. Managing tropical rice pests through conservation of generalist natural enemies and alternative prey. Ecology, 77 (7): 1975-1988.

Shaxson, F. y Barber, R.

2005. Optimización de la humedad del suelo para la producción vegetal. El significado de la porosidad del suelo. Boletín de suelos de la FAO 79. Organización de las Naciones Unidas para la Agricultura y la Alimentación. Roma, Italia. 111 p.

Szendrei, Z. y Weber, D.

2009. Response of predators to habitat manipulation in potato fields. Biological Control 50 (2): 123-128. 